\title{
SMARTBIN FEJLESZTÉSE KIBER-FIZIKAI HULLADÉKGYÜJTÉSI RENDSZER KIALAKÍTÁSÁHOZ
}

\author{
Cservenák Ákos \\ tudományos segédmunkatárs, Miskolci Egyetem, Logisztikai Intézet \\ 3515 Miskolc, Miskolc-Egyetemváros, e-mail: cservenak.akos@uni-miskolc.hu \\ Bányai Tamás \\ egyetemi docens, Miskolci Egyetem, Logisztikai Intézet \\ 3515 Miskolc, Miskolc-Egyetemváros, e-mail: alttamas@uni-miskolc.hu
}

\begin{abstract}
Absztrakt
A cikk bemutatja egy szokásos, üzletben is megvásárolható hulladékgyüjtő edény továbbfejlesztését. Ez az edény képes kimutatni az aktuális telitettséget, közeledés esetén automatikusan nyitni-zárni a fedelet, valamint online felület segitségével a telitettséget távolról is megjeleniteni. A cikk részletezi a továbbfejlesztés mechanikai, elektronikai és programozási oldalát.
\end{abstract}

Kulcsszavak: mechatronika, logisztika, hulladékgyüjtés, autonóm rendszer

\begin{abstract}
This article introduces a further development of a standard commercial waste bin. This dustbin is able to detect its current load, open-close its cover automatically, and remote access the load level using online interface. The purpose of this article is to describe the mechanical, electronics and programming side.
\end{abstract}

Keywords: mechatronics, logistics, waste collection, autonomous system

\section{Bevezetés}

Napjainkban a negyedik ipari forradalom révén az automatizálás egyre jelentősebb hatást fejt ki a rendszerek és eszközök automatizálásának területén, beleértve a háztartásokat és az egészségügyet is. Egy szemetes tartályt legtöbbször kézzel müködtetnek és ürítenek ki, de manapság már ki lehet üríteni automatizált úton, például egy tisztító robottal [1]. A Miskolci Egyetem Logisztikai Intézetében egy olyan szokásos, üzletben is megvásárolható hulladékgyüijtő tartály továbbfejlesztése került megvalósításra, mely során a cél annak automatizálása volt. Ezen automatizálás keretében a fedél nyitása és zárása, valamint a telítettségi információ-visszacsatolás került megvalósításra. Kialakítottunk és integráltunk egy valós idejü diagnosztikai megoldást is, amely lehetővé teszi ennek a SmartBin-nek a kiber-fizikai hulladékgyüjtő rendszerbe történő beépítését és az összegyüjtött adatok Wi-Fi kapcsolaton keresztül történő továbbítását, ideértve a hulladék szintjének küldését időbélyegzővel kiegészítve a felhőbe [2]. Ezenkívül biztonsági okokból a rendszer fény és hangjelzéssel figyelmeztet, amikor bezáródik. A továbbfejlesztett megoldásunk lehetőséget kínál a jövőbeli hulladékszint előrejelzésére és a gyüjtési útvonalak előzetes ütemezésére. Ezen megoldás lehetővé teszi a hagyományos kommunális hulladékgyüjtési rendszerek járatkihasználtságának fokozását és a szolgáltatási színvonal növelését a valós idejü járattervezés feltételeinek megteremtése révén [3]. Egy SmartBin használható egy élelmiszertípus begyüjtési állapotának megállapítására is [4]. 
A fejlesztés során elöször a mechanikai kialakítást készítettük el, ezt ismerteti a 2. fejezet. A szemetesbe két ultrahangos érzékelőt (továbbiakban UH szenzor) a távolságok érzékeléséhez, 6 LEDet a visszajelzésre, amit lehetne LCD kijelző segítségével is [5], továbbá egy mikrovezérlőt a vezérléshez és egy szervót a fedél mozgatásához építettünk be [6]. Az összeszerelés után az elektronikus áramkört megterveztük és kábelekkel, csatlakozókkal és más elektronikus elemekkel összeépítettük, ahogy a 3. fejezet részletezi. A SmartBin tápellátását USB csatlakozásról lehet megvalósítani. A 4. fejezet a programozásra tér ki. Végül az utolsó fejezet összefoglaló megállapításokat tesz, és kitér a továbbfejlesztési lehetőségekre is.

\section{Mechanikai összeállítás}

A mechanikai összeállítás során az a törekvés volt, hogy az elektronikai elemeket megfelelően be lehessen építeni, valamint a fedél mozgatása is megvalósuljon. A szemetesgyüjtő edény gyárilag 3 részből áll: alsó rész, felső rész és felső részben mozgatható fedél.

Az előbb említetteken felül ajánlatos volt a fedélhez vagy a felső részhez társítani az elemeket. A szemét ürítésekor le kell venni a felső részt, és ha ilyenkor az alsó részhez is lennének rögzítve elemek, a kábelek csak egy bizonyos mértékben engednék a levételt, vagy rosszabb esetben el is szakadnának.

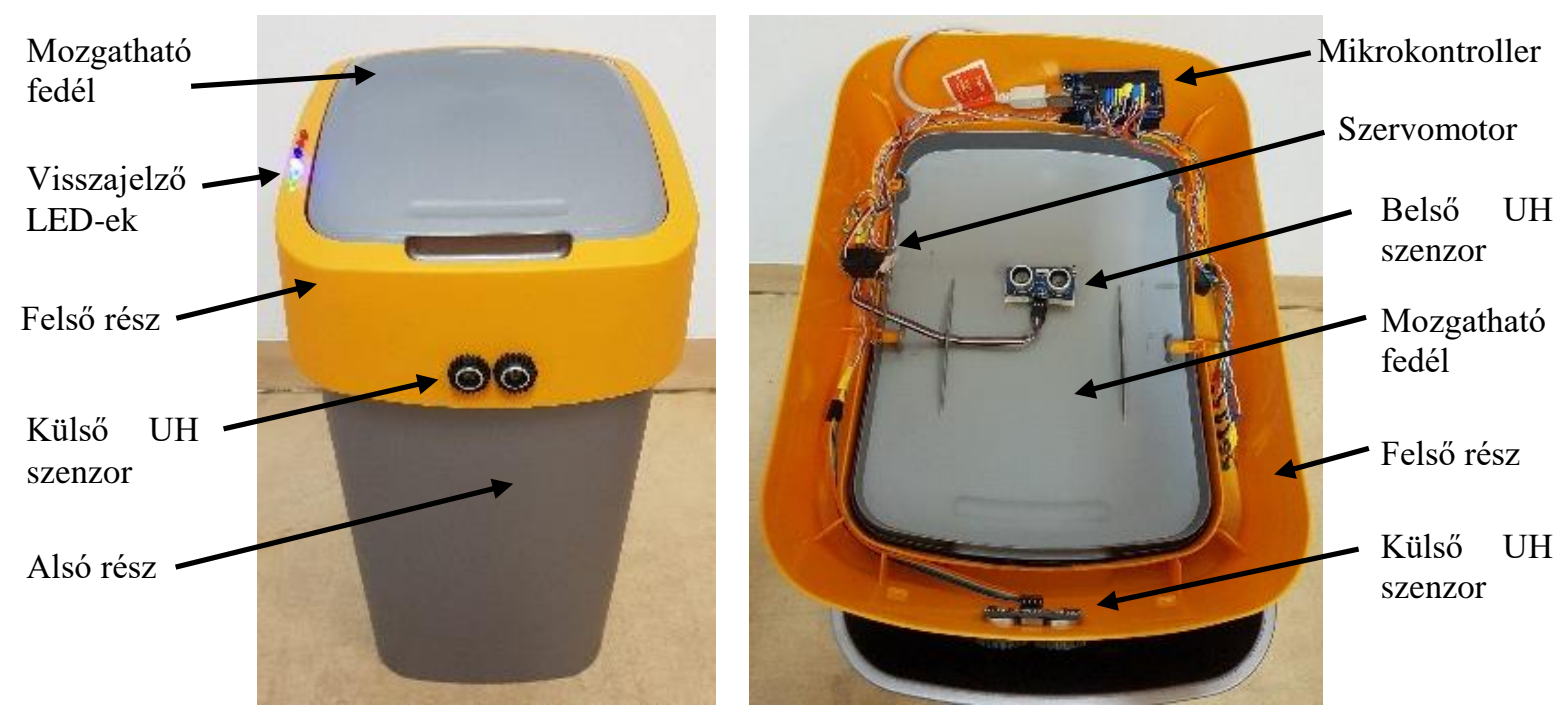

1. ábra. Továbbfejlesztett szemetesgyüjtö edény

A fedél mozgatásáért egy kereskedelemben kapható, leginkább RC (rádiótávirányításos) modellekben használatos szervomotor felelős. Ez a szervomotor egy egyszerü mechanizmus segítségével valósítja meg a fedél mozgatását. A szervomotor a felső részhez került rögzítésre, míg a mechanizmusért felelős kar két vége a szervomotor által rögzített kar végénél és a mozgatandó fedél középpontjához közeli pontjához került elhelyezésre.

A külső környezet figyeléséért felelős HC-SR04 UH szenzor az edény felső részében került beépítésre úgy, hogy az alsó résszel ne ütközzön. A másik, ugyanilyen típusú UH szenzor a fedélre került elhelyezésre, amely így függőlegesen tudja figyelni a telítettséget. 
A visszajelzésért felelös LED-ek a felső rész oldalán, függőlegesen kifelé állnak, hogy a fedél fölött állva bármilyen szögből látható legyen a telítettség. A további elemek, mint a mikrovezérlö, feszültségelosztó, kábelek, a felső rész belső pereme mentén helyezkednek el. A kész összeállítás az 1. ábrán látható.

\section{Elektronikai összeállítás}

A mechanikai kialakítás után következett az elektronikai rész összeállítása egy kapcsolási rajz alapján. Az UH szenzorok és a szervomotor $5 \mathrm{~V}$ tápellátást igényelnek, így a mikrovezérlőről két kábel $(+5 \mathrm{~V}$ és $0 \mathrm{~V}$ ) csatlakozik egy elosztóba, innen megy tovább 3-3 vezeték.

Az UH szenzorok továbbá igényelnek 1-1 vezetéket a „Trig” pinre, amely müködtetésével a szenzor kibocsátja az ultrahangot, valamint 1-1 vezetéket az „Echo” pinre, amely a kibocsátott és visszaérkező ultrahang közötti időt lehet érzékelni. A vezetékek másik vége a mikrovezérlő 1-1 digitális I/O lábára csatlakozik.

A szervomotor igényel egy jelvezetéket, amelyen PWM modulált jel segítségével tudja a szervokar helyzetét mozgatni. A LED-ek katódjai egy közös $0 \mathrm{~V}$ potenciálra csatlakoznak, míg az anód 1-1 előtét ellenállás segítségével csatlakozik a mikrovezérlő 1-1 digitális kimenetére. A hangjelzésért egy körülbelül 30mm átmérőjü hangszóró felelős, amelynek egyik lába a $0 \mathrm{~V}$ potenciálra csatlakozik, míg a másik lába a mikrovezérlő digitális kimenetével van összeköttetésben. Maga a mikrovezérlő az USB-B aljzaton keresztül kapja a tápellátást. Ide egy USB-A és USB-B végü kábel segítségével bármilyen USB-A csatlakozóval rendelkező egységre lehet csatlakoztatni, mint például PC, mobiltelefon töltő vagy hordozható powerbank. Ez utóbbival az akkumulátoros tápellátás is megoldható. A rendszerhez tartozó elektronikai kapcsolás (2. ábra) a Fritzing szoftverben készült.

UH szenzor 1

UH szenzor 2

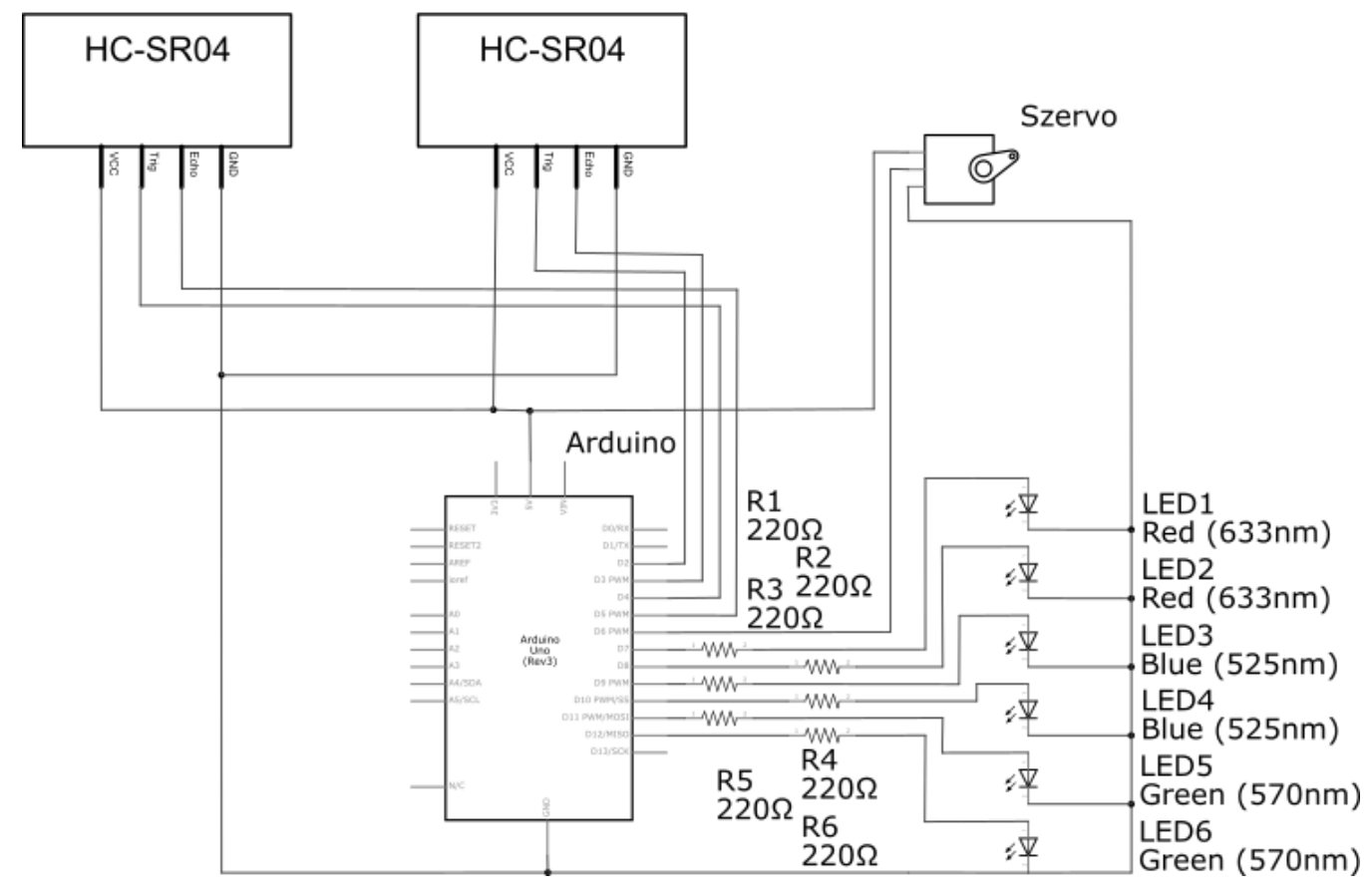

2. ábra. Továbbfejlesztett szemetesgyüjtő edény elektronikai kapcsolása 


\section{Programozás}

A programozás során először az egyes funkciókat írtuk meg, mint a nyitás-zárás, külső-belső távolságmérés, LED-ek vezérlése különböző esetekben. Végül a föprogram került megírásra, amely az egyes funkciókat hívja a szükséges esetekben.

Alapvetően 3 üzemmódról lehet szó:

1. A fedél zárva van

2. A fedél nyitva van

3. A fedél záródik

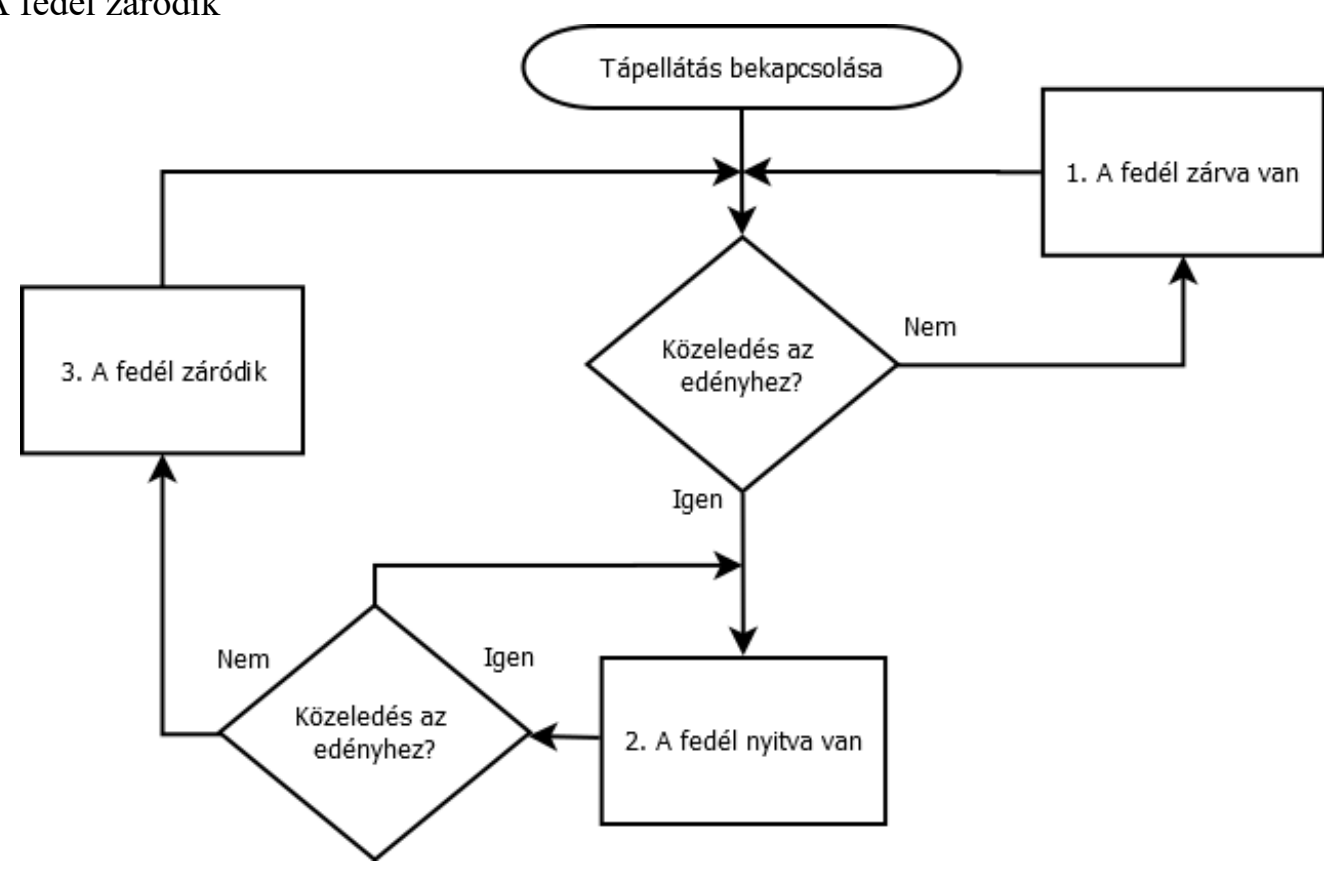

3. ábra. Továbbfejlesztett szemetesgyüjtö edény elektronikai kapcsolása

A legtöbbször zárva lesz a fedél, ebben az esetben a telítettséget mutatja LED-ek segítségével, felhasználva a belső UH szenzor jelét, valamint a külső környezetet figyeli a külső UH szenzor jelével. Amennyiben közeledést érzékel a külső UH szenzor, akkor a fedél nyitása után átvált a 2. üzemmódra. Ekkor a LED lassúbb, sorozatos villogtatásával jelzi, hogy nyitva van a fedél. Amennyiben távolodást érzékel a külső UH szenzor, akkor a 3. üzemmód lesz aktív, ennek során hangjelzéssel és a LED-ek gyorsabb tempójú villogtatásával figyelmeztet a rendszer, és 2 másodperc után záródik a fedél. A fedél bezáródása után, amennyiben nincs közeledés, akkor az 1. üzemmód lesz aktív, egyébként visszatér a 2. üzemmódba. A megírt program folyamatábráját a 3. ábra részletezi.

\section{5. Összefoglalás}

A cikk bemutatta egy kereskedelemben kapható hulladékgyüjtő tartály továbbfejlesztését. A fejlesztés során beépítésre kerültek különböző elektronikai elemek, amelyek a környezet és a belső tartalom figyeléséért, a nyitás-zárásért és a visszajelzésekért felelös. Az egyes elemek elektronikailag is be lettek kötve, valamint a mikrovezérlőn megtörtént a programozás. Megállapítható, hogy a rendszer müködőképes, és stabilan müködik. Továbbfejlesztési tervként az online felület fejlesztése jön szóba. 
Ennek legfőbb oka az, hogy jövőbeli kutatási terveink között szerepel egy nagyméretű hulladékgyüjtő konténer mechatronikai átalakítása annak érdekében, hogy az illeszthető legyen egy kommunális kiber-fizikai hulladékgyüjtő rendszerbe. A hulladékgyüjtő konténer átalakításával és az online diagnosztika biztosításával olyan új valós idejü optimalizálási lehetőségek válnak elérhetővé, melyek révén a teljes hulladékgyüjtési rendszer kihasználtsága és rendelkezésre állása, valamint a szolgáltatás színvonala fokozható.

\section{Köszönetnyilvánítás}

A cikkben ismertetett kutató munka az EFOP-3.6.1-16-2016-00011 jelü „Fiatalodó és Megújuló Egyetem - Innovatív Tudásváros - a Miskolci Egyetem intelligens szakosodást szolgáló intézményi fejlesztése" projekt részeként - a Széchenyi 2020 keretében - az Európai Unió támogatásával, az Európai Szociális Alap társfinanszírozásával valósul meg.

\section{Irodalom}

[1] Li, Z., Huang, Z.: Design of a type of cleaning robot with ultrasonic (2013) Journal of Theoretical and Applied Information Technology, 47 (3), pp. 1218-1222.

[2] Fataniya, B., Sood, A., Poddar, D., Shah, D.: Implementation of IoT based waste segregation and collection system (2019) International Journal of Electronics and Telecommunications, 65 (4), pp. 579-584.

[3] Ganesh, N., Narayanan, R.C.: Collection of garbage using internet of things (2019) International Journal of Engineering and Advanced Technology, 8 (6), pp. 3481-3483. https://doi.org/10.35940/ijeat.F9523.088619

[4] Galeas, P., Muñoz, C., Huircan, J., Fernandez, M., Segura-Ponce, L.A., Duran-Faundez, C.: Smartbins: Using intelligent harvest baskets to estimate the stages of berry harvesting (2019) Sensors (Switzerland), 19 (6), art. no. 1361. https://doi.org/10.3390/s19061361

[5] Manoharan, S., Janani, T., Jagadeesh, P., Jeevan Raju, M., Bhuvaneswari, G.: Design and development of automated dumpster management system (2019) International Journal of Innovative Technology and Exploring Engineering, 8 (8), pp. 29-33.

[6] Dhana Shree, K., Janani, B., Reenadevi, R., Rajesh, R.: Garbage monitoring system using smart bins (2019) International Journal of Scientific and Technology Research, 8 (11), pp. 1921-1925. 